Reformation Theology for a Post-Secular Age

Løgstrup, Prenter, Wingren, and the Future of Scandinavian Creation Theology

Gregersen, Niels Henrik; Kristensson Uggla, Bengt; Wyller, Trygve

Publication date:

2017

Citation for published version (APA):

Gregersen, N. H., Kristensson Uggla, B., \& Wyller, T. (red.) (2017). Reformation Theology for a Post-Secular Age: Løgstrup, Prenter, Wingren, and the Future of Scandinavian Creation Theology. Vandenhoeck \& Ruprecht. Research in Contemporary Religion Bind 24 
Niels Henrik Gregersen / Bengt Kristensson Uggla / Trygve Wyller (eds.)

\section{Reformation Theology for a Post-Secular Age: Løgstrup, Prenter, Wingren, and the Future of Scandinavian Creation Theology}

Vandenhoeck \& Ruprecht 


\section{Contents}

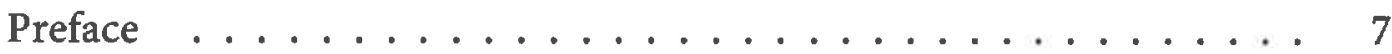

Niels Henrik Gregersen, Bengt Kristensson Uggla and Trygve Wyller

1. Reconfiguring Reformation Theology: The Program of Scandinavian Creation Theology .................... 11

PART I: FOUNDING FIGURES . . . . . . . . . . . 35

Niels Henrik Gregersen

2. K.E. Løgstrup and Scandinavian Creation Theology _. . . . . . 37

Christine Svinth-Voerge Põder

3. Regin Prenter and Scandinavian Creation Theology . . . . . . . . . 67

Bengt Kristensson Uggla

4. Gustaf Wingren and Scandinavian Creation Theology . . . . . . . 91

PART II: SEMINAL SOURCES . . . . . . . . . . . . . . 113

Allen G. Jorgenson

5. Martin Luther in Scandinavian Creation Theology . . . . . . . . 115

A.M. Allchin

6. N.F.S. Grundtvig: The Earth Made in God's Image . . . . . . . . . 127

PART III: CONTEMPORARY CONCERNS AND CHALLENGES . . 145

Ole Jensen

7. Creation Theology and the Confrontation with Speciecism:

Memories and Reflections . . . . . . . . . . . . . . . 147

Jakob Wolf

8. Phenomenology in Løgstrup's Creation Theology . . . . . . . . . . 157 


\section{Pia Søltoft}

9. C.S. Lewis, K.E. Løgstrup and Kierkegaard on Love's Erotic

Dimension . . . . . . . . . . . . . . . . . 167

Elisabeth Gerle

10. Human Rights: Revisiting the Political Program of Scandinavian

Creation Theology . . . . . . . . . . . . . . . . 179

Benedicte Hammer Prostholm

11. The Theology of the Unchangeable Gender and the Challenge from

Scandinavian Creation Theology . . . . . . . . . . . . 191

Trond Skard Dokka

12. Universal and Particular: Creation Theology and Ecclesiology in a

Fragmented World . . . . . . . . . . . . . . . 201

Jakob Wirén

13. Wingren and the Theology of Religions: Inter-Religious

Hermeneutics . . . . . . . . . . . . . . . . . . 215

PART IV: THEOLOGICAL AND SOCIAL CONTEXTS $\ldots \ldots . . . .227$

Jan-Olav Henriksen

14. The Economic Trinity and Creation . . . . . . . . . . 229

Derek R. Nelson

15. Scandinavian Creation Theology in American Perspective . . . 241

Trygve Wyller

16. The Discovery of the Secular-Religious Other in the Scandinavian

Creation Theology . . . . . . . . . . . . . . . . . . . 253

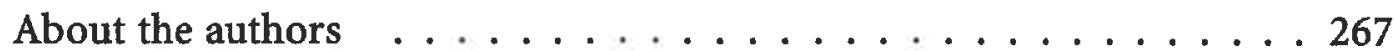

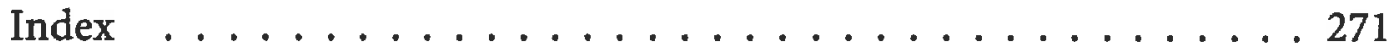




\section{Preface}

The aim of the present volume is to offer a concise and multifaceted introduction to the Scandinavian creation theology movement. International Luther scholars and systematic theologians alike will know the names K.E. Løgstrup, Regin Prenter and Gustaf Wingren, if not by having read some of their works themselves, then by having heard others talk about them. In this book, we present their distinctive theologies for an international audience, and in so doing, we hope we will have accomplished three interdependent goals.

The first aim is to offer intellectual portraits and detailed theological interpretations of the three founding figures of Scandinavian creation theology: Løgstrup, Prenter and Wingren. Here, we have focused on their individual contributions to the emergence of Scandinavian creation theology. This movement came about in the mid-twentieth century, was developed in the latter half of that century, and has continued to influence the cultural climate of Scandinavian theology since then. In their own life times, Løgstrup, Prenter, and Wingren were recognized names in Scandinavia as well as in Germany. Due to new American editions, K.E. Løgstrup and Gustaf Wingren are becoming familiar names through the English-speaking world too.

The second aim is to argue that Scandinavian creation theology offers a model for reconfiguring Reformation theology for a post-secular age. "Postsecularity," in our interpretation, does not mean taking leave of secularity. Rather, a post-secular age is a cultural climate in which the boundaries between what is secular and what is religious have become more porous, so that secular mind-sets and religious affirmations of everyday life may co-exist both in public discourse, and at the level of individual secular-religious commitments. In the context of the 2017 commemorations of the 500 years since the Reformation, we argue that the program of Scandinavian creation theology offers a unique resource for rethinking the Reformation heritage.

Scandinavian creation theology combines seminal insights from the creation theology of Martin Luther (1483-1546) with central aspects of the so-called "Mosaic-Christian view of life" proposed by the Danish theologian N.F.S. Grundtvig (1783-1872). In contrast to Luther, Grundtvig argued that human beings never lost the positive traces of being "created in the image and likeness of God." Accordingly, the Christian triad of faith, hope and love, can be recognized, appreciated, and to some extent also exercised by non-believers. 
With his principle, "human first, then Christian," Grundtvig argued that a broader understanding and appreciation of naturally lived human experience should be the underlying condition for the Christian way of life, serving as the horizon for understanding the Christian church, its confessions and the sacraments. Christian faith has to be lived in a humane way, in accordance with a shared sense of humanity. Thus, for proponents of Scandinavian creation theology, Grundtvig serves as the mediator and bridge-builder between a premodern Lutheranism and a contemporary secular-religious age. This combination of Luther and Grundtvig, however, does raise a set of significant theological questions. Exactly how is the relationship between humanity and the Christian message to be understood? To what extent are philosophical arguments viable within Christian theology? And, finally, how does Grundtvig's motto, "Human first, ..." square with Luther's principle of simul justus et peccator?

The third aim of the present volume is to reconsider the future of Scandinavian creation theology in the light of other contemporary Christian theological trends. In their own time, Løgstrup, Prenter, and Wingren took issue with both the expansiveness of Karl Barth's church theology, and with Rudolf Bultmann's more restrictive existentialist theology. We argue that Scandinavian creation theology takes a similar stance vis-à-vis the more expansionist programs of Radical Orthodoxy, and the more internalist views of what it means to be a Christian characteristic of Postliberal Theology and strands similar to it in contemporary theology. Indeed, Scandinavian creation theology stands and falls with the claim that there are shared aspects of human life that offer room for open-minded discussions of how to live the human condition alongside people of other faiths, and with people of no professed faith at all.

Scandinavian creation theology leaves ample room for common sense and common commitments, even where worldviews differ or even drift apart. Everyday life constitutes a third realm between a purely political realm, and a purely religious domain. Accordingly, the role of Christian theology is to keep open the shared horizons of human co-existence, whilst being acutely aware of the particularity of the gospel, which is likewise aimed at all people. Today, new questions challenge Scandinavian creation theology. Needless to say, Scandinavian creation theology is not interested in establishing an ethnic theology for Scandinavians. To the contrary, Scandinavian creation theology is not centered on identity politics, and is sharply critical of self-profiling attitudes within churches or other religious communities wanting to bolster themselves over and against their surrounding cultures. Put simply, we need to examine the relationship between "common sense" and the legitimate concerns expressed in the form of particular communities, where each brings their own visions of "communal sense" into the public discussions. Here, the Scandinavian program raises a new set of questions with respect to its place in the larger theological whole. For example, what are the relationships between Scandinavian creation theology and contemporary trends such as ecotheology, gender theology, 
interreligious dialogue, the human rights movements, and so on? All these questions will be considered at length throughout the book.

We have many to thank for making this publication possible. The idea for the book itself came from the Grundtvig Research Centre, Aarhus University. In collaboration with the three editors, the Director of the Grundtvig Research Centre, Dr. Michael Schelde organized an explorative conference on "The Future of Scandinavian Creation Theology: Martin Luther and N.F.S. Grundtvig Revisited," which took place at Vartov in the centre of Copenhagen, August 24-26, 2014. The conference hosted both the authors and other attendants, and produced a very fruitful conference, pointing forward to this publication. Our deep gratitude goes to Dr. Schelde, who has generously supported the present project, both in its initial and later phases, and both in terms of commitment and resources. Also, we gratefully acknowledge the excellent work done by Dr. Harris Wiseman, Cambridge, in improving the language for those of us who are not native English speakers. Dr. Wiseman understood our project, and was able to make our texts more fluid than they might otherwise have been. Any remaining errors lie entirely on the shoulders of the editors. We also thank the Grundtvig Research Centre for the permission to reprint an important chapter of A.M. Allchin, N.F.S. Grundtvig: An Introduction to his Life and Work (Aarhus University Press 2015), printed here as Chapter 6.

The editors also wish to thank the authors of this book for their patience and attentiveness to all our many requests during the publication process. They have provided excellent and original work, both in analyzing the situation and in their constructive proposals. Warm thanks also go to Søren Frank Jensen, student of theology, who (again) has done a very meticulous job as the copy editor of the book, also providing the book with an index.

We are grateful to the editors of the series "Research in Contemporary Religion" at Vandenhoeck \& Ruprecht, who have kindly included this book in the RCR series. Particularly, we thank Professor Hans-Günter Heimbrock who has been in charge of the peer review process, and who has offered substantial inputs and guidelines for the book. Finally, we thank Jörg Persch and Moritz Reissing at Vandenhoeck \& Ruprecht who have served as editorial directors for the field of theology and religion.

A final practical note: All references to the works of Martin Luther are either to D. Martin Luthers Werke. Kritische Gesamtausgabe 1-80 (Weimar: Hermann Böhlaus und Nachfolger), abbreviated as WA, or to Luther's Works 1-78 (Minneapolis: Fortress Press/Saint Loius: Concordia Publishing House), abbreviated as LW.

Copenhagen-Stockholm-Oslo

September 12, 2016

Niels Henrik Gregersen, Bengt Kristensson Uggla, and Trygve Wyller 